University of Nebraska - Lincoln

DigitalCommons@University of Nebraska - Lincoln

A new species of nectar-feeding bat, genus Lonchophylla, from western Colombia and western Ecuador (Mammalia: Chiroptera: Phyllostomidae)

Neal Woodman

USGS Patuxent Wildlife Research Center, woodmann@si.edu

Follow this and additional works at: https://digitalcommons.unl.edu/usgsstaffpub

Woodman, Neal, "A new species of nectar-feeding bat, genus Lonchophylla, from western Colombia and western Ecuador (Mammalia: Chiroptera: Phyllostomidae)" (2007). USGS Staff -- Published Research. 623.

https://digitalcommons.unl.edu/usgsstaffpub/623

This Article is brought to you for free and open access by the US Geological Survey at DigitalCommons@University of Nebraska - Lincoln. It has been accepted for inclusion in USGS Staff -- Published Research by an authorized administrator of DigitalCommons@University of Nebraska - Lincoln. 


\title{
A new species of nectar-feeding bat, genus Lonchophylla, from western Colombia and western Ecuador (Mammalia: Chiroptera: Phyllostomidae)
}

\author{
Neal Woodman
}

USGS Patuxent Wildlife Research Center, National Museum of Natural History, MRC-111, Smithsonian Institution, Washington, D.C. 20013-7012, U.S.A., e-mail: woodmann@si.edu

\begin{abstract}
The twelve recognized species of nectar-feeding bats of the genus Lonchophylla occur in low- and middle-elevation, humid, Neotropical forests. Morphological and morphometrical analyses of specimens formerly lumped with Lonchophylla mordax O. Thomas (1903) support recognition of Lonchophylla concava Goldman (1914) as a separate species and reveal a third species from the western Pacific lowlands of Colombia and Ecuador that I describe herein as Lonchophylla fornicata. This new species is morphologically similar to Lonchophylla concava but is distinctively larger than that species. Tests for sexual dimorphism within these and other species of Lonchophyllini suggest a tendency for females to have slightly longer, narrower skulls, higher coronoid processes of the mandible, and longer forearms than males.
\end{abstract}

The genus Lonchophylla includes twelve species of nectar-feeding bats that are distributed primarily in tropical, low- to mid-elevation forests from southern $\mathrm{Ni}$ caragua south to southern Peru, Bolivia, and southeastern Brazil (Koopman 1994, Dávalos 2004, Albuja \& Gardner 2005, Woodman \& Timm 2006). Recent phylogenetic analyses confirm a close relationship among Lonchophylla and the monotypic genera Lionycteris, Platalina, and Xeronycteris (Dávalos \& Jansa 2004, Gregorin \& Ditchfield 2005, Woodman and Timm 2006), which together comprise a specialized monophyletic lineage (tribe Lonchophyllini) within the phyllostomid subfamily Glossophaginae (Wetterer et al. 2000, Carstens et al. 2002, Baker et al. 2003, Gregorin \& Ditchfield 2005, Simmons 2005). In fact, molecular and combined molecular and morphological analyses indicate that Lonchophylla may be paraphyletic with respect to one or more of these other three genera (Baker et al. 2003, Dávalos and Jansa 2004, Gregorin \& Ditchfield 2005). De- spite these possible relationships, the four genera as currently understood are easily distinguished from one another using suites of morphological characters (Woodman \& Timm 2006).

While investigating variation within and among species of Lonchophyllini in order to better understand and describe Lonchophylla cadenai and Lonchophylla pattoni (Woodman \& Timm, 2006), I encountered specimens of a distinctive Lonchophylla from the Pacific lowlands in southwestern Colombia and northwestern Ecuador. These specimens represent a previously unrecognized species that is most similar morphologically to, but distinct from, Lonchophylla concava (Goldman, 1914). Herein, I describe this new species and explain its relationships with other species in the genus.

\section{Materials and Methods}

Measurements (mm) follow those of Woodman \& Timm (2006), who described and illustrated the skull dimen- 
sions used herein. Forearms and skulls were measured to the nearest $0.1 \mathrm{~mm}$ using a digital caliper or an ocular micrometer in a dissecting microscope. With the exception of length of forearm, external measurements are those recorded by the original collectors. Length of head and body was determined by subtracting tail length from total length. Length of forearm was measured from the elbow to the distal-most extension of the bent wrist. Abbreviations used for measurements are provided in Table 1. Capitalized color terms are those of Ridgway (1912). In descriptions of habitats, capitalized vegetational associations are from the Holdridge system for classification of life zones (Holdridge 1947, Holdridge et al. 1971). Specimens examined for this study are listed in Appendix I.

The new species that I describe herein is most similar in size and morphology to Lonchophylla concava Goldman (1914), and specimens of the new species were initially identified as belonging to that species (e.g., Woodman \& Timm 2006: 475). Lonchophylla concava generally has been treated as a subspecies of Lonchophylla mordax O. Thomas (1903) since Handley's (1966) study of Panamanian Lonchophylla. However, I agree with Albuja \& Gardner's (2005) recognition of $L$. concava and $L$. mordax as distinct species. The two taxa are similar in size (Table 1) but differ in a number of qualitative skull characters (Woodman \& Timm 2006).

In order to compare the new species with $L$. concava and to determine whether the former's larger size could be explained by clinal variation in $L$. concava, I carried out principal components analyses (PCA) using a correlation matrix of eight variables (GLS, PL, SB, ZB, UTL, LTL, $\mathrm{CPH}, \mathrm{FAL})$ and plotted the resulting scores. Because of the long time span during which $L$. concava and $L$. mordax were considered conspecific, I included $L$. mordax in some of these comparisons.
Variables for these analyses were measured from seven individuals of the new species from Colombia and Ecuador; 37 L. concava from Colombia $(n=2)$, Costa Rica (9), Ecuador (8), and Panama (18); and 23 L. mordax from Brazil.

To investigate sexual dimorphism in $L$. concava, L. mordax, and the new species, I compared selected variables within species using Student's $t$-tests for small samples of equal or unequal size, as appropriate (Sokal \& Rohlf 1981). I plotted PCA factor scores of female and male $L$. concava separately for one of the analyses and inspected the plots for patterns of differentiation. In addition, I looked for common, albeit non-significant, patterns of sexual variation among my samples and among Woodman \& Timm's (2006) samples of Lionycteris spurrelli and Lonchophylla thomasi.

I reinvestigated the phylogeny of the Lonchophyllini (Lonchophylla, Lionycteris, Platalina, Xeronycteris) using 64 characters in a dataset (Appendix II) modified slightly from that used by Woodman \& Timm (2006). This dataset included 26 morphological and mDNA restriction site characters from Wetterer et al.'s (2000) analysis of the Phyllostomidae. One major departure from Woodman \& Timm's (2006) dataset was the deletion of their character 57 , which was redundant with regard to characters 54 56. In addition, I was able to code selected characters not previously provided for $L$. bokermanni from a single specimen (TTU 43627). Because previous analyses of the Phyllostomidae (Baker et al. 2003, Wetterer et al. 2000, Carstens et al. 2002) suggested a variety of possible outgroup relationships for the Lonchophyllini, I included seven non-Lonchophyllini species of Phyllostomidae to polarize characters: Anoura geoffroyi, Glossophaga soricina, and Monophyllus redmani (Glossophaginae, Glossophagini); Carollia perspicillata (Carolliinae); Erophylla sezekorni and Phyllonycteris 
Table 1.- Skull and external measurements of males and females of three species of Lonchophylla. Statistics are mean $\pm S D$, with observed extremes. Abbreviations used for measurements are given in parentheses.

\begin{tabular}{|c|c|c|c|c|c|c|}
\hline \multirow[b]{2}{*}{ Character } & \multicolumn{2}{|c|}{ Lonchophylla fornicata } & \multicolumn{2}{|c|}{ Lonchophylla concava } & \multicolumn{2}{|c|}{ Lonchophylla mordax } \\
\hline & females $(n=4)^{1}$ & males $(n=4)^{1}$ & females $(n=12)^{1}$ & males $(n=27)^{1}$ & females $(n=15)$ & males $(n=7)$ \\
\hline $\begin{array}{l}\text { Greatest length of } \\
\text { skull (GLS) }\end{array}$ & $\begin{array}{c}24.7 \pm 0.6 \\
24.1-25.4\end{array}$ & $\begin{array}{c}24.3 \pm 0.4 \\
23.7-24.6\end{array}$ & $\begin{array}{c}23.4 \pm 0.5 \\
22.6-24.2\end{array}$ & $\begin{array}{c}23.2 \pm 0.5 \\
22.0-24.0\end{array}$ & $\begin{array}{c}23.3 \pm 0.4 \\
22.5-23.7\end{array}$ & $\begin{array}{l}23.2 \pm 0.6 \\
22.0-24.0\end{array}$ \\
\hline Condylobasal & $23.4 \pm 0.5$ & $22.9 \pm 0.3$ & $21.9 \pm 0.6$ & $21.7 \pm 0.6$ & $21.4 \pm 0.4$ & $21.3 \pm 0.7$ \\
\hline length (CBL) & $22.9-23.9$ & $22.5-23.2$ & $20.7-22.6$ & $\begin{array}{l}20.1-22.4 \\
(n=25)\end{array}$ & $20.9-21.9$ & $20.1-22.1$ \\
\hline Palatal length (PL) & $\begin{array}{c}13.3 \pm 0.8 \\
12.7-14.4\end{array}$ & $\begin{array}{c}13.1 \pm 0.4 \\
12.7-13.5\end{array}$ & $\begin{array}{c}12.5 \pm 0.5 \\
11.3-13.1\end{array}$ & $\begin{array}{c}12.2 \pm 0.4 \\
11.1-13.0\end{array}$ & $\begin{array}{c}11.5 \pm 0.2 \\
11.1-11.9\end{array}$ & $\begin{array}{c}11.4 \pm 0.5 \\
10.6-12.3\end{array}$ \\
\hline $\begin{array}{l}\text { Supraorbital } \\
\text { breadth (SB) }\end{array}$ & $\begin{array}{l}4.6 \pm 0.2 \\
4.44 .8\end{array}$ & 4.6 & $\begin{array}{c}4.4 \pm 0.1 \\
4.1-4.9\end{array}$ & $\begin{array}{l}4.5 \pm 0.2 \\
4.2-4.9\end{array}$ & $\begin{array}{l}4.3 \pm 0.1 \\
4.1-4.5\end{array}$ & $\begin{array}{l}4.3 \pm 0.1 \\
4.1-4.4\end{array}$ \\
\hline $\begin{array}{l}\text { Zygomatic breadth } \\
\quad \text { (ZB) }\end{array}$ & $\begin{array}{l}9.5 \pm 0.2 \\
9.3-9.8\end{array}$ & $\begin{array}{l}9.6 \pm 0.2 \\
9.3-9.8\end{array}$ & $\begin{array}{l}8.9 \pm 0.1 \\
8.8-9.0 \\
(n=11)\end{array}$ & $\begin{array}{l}9.2 \pm 0.3 \\
8.5-9.6\end{array}$ & $\begin{array}{l}9.1 \pm 0.2 \\
8.7-9.4\end{array}$ & $\begin{array}{l}9.1 \pm 0.3 \\
8.8-9.6\end{array}$ \\
\hline $\begin{array}{l}\text { Breadth of } \\
\text { braincase (BB) }\end{array}$ & $\begin{array}{l}9.3 \pm 0.2 \\
9.2-9.5\end{array}$ & $\begin{array}{l}9.1 \pm 0.1 \\
9.0-9.2\end{array}$ & $\begin{array}{c}8.9 \pm 0.1 \\
8.6-9.0\end{array}$ & $\begin{array}{l}9.0 \pm 0.2 \\
8.6-9.3\end{array}$ & $\begin{array}{l}8.5 \pm 0.1 \\
8.3-8.8\end{array}$ & $\begin{array}{c}8.6 \pm 0.2 \\
8.3-8.8\end{array}$ \\
\hline $\begin{array}{l}\text { Mastoid breadth } \\
\text { (MB) }\end{array}$ & $\begin{array}{l}9.6 \pm 0.1 \\
9.5-9.6\end{array}$ & $\begin{array}{l}9.5 \pm 0.1 \\
9.4-9.6\end{array}$ & $\begin{array}{l}9.2 \pm 0.2 \\
8.8-9.4\end{array}$ & $\begin{array}{l}9.3 \pm 0.2 \\
8.9-9.7\end{array}$ & $\begin{array}{l}9.1 \pm 0.2 \\
8.8-9.3\end{array}$ & $\begin{array}{l}9.3 \pm 0.2 \\
9.0-9.6\end{array}$ \\
\hline $\begin{array}{l}\text { Length of } \\
\text { maxillary } \\
\text { toothrow (UTL) }\end{array}$ & $\begin{array}{l}8.3 \pm 0.1 \\
8.1-8.4\end{array}$ & $\begin{array}{l}8.2 \pm 0.3 \\
7.8-8.5\end{array}$ & $\begin{array}{l}7.7 \pm 0.2 \\
7.2-8.1\end{array}$ & $\begin{array}{c}7.7 \pm 0.2 \\
7.3-8.1\end{array}$ & $\begin{array}{l}7.8 \pm 0.2 \\
7.4-8.1\end{array}$ & $\begin{array}{l}7.9 \pm 0.3 \\
7.5-8.2\end{array}$ \\
\hline $\begin{array}{l}\text { Breadth across } \\
\text { upper molars } \\
\text { (MMB) }\end{array}$ & $\begin{array}{l}5.4 \pm 0.1 \\
5.3-5.5\end{array}$ & $\begin{array}{c}5.6 \pm 0.2 \\
5.4-5.7 \\
(n=3)\end{array}$ & $\begin{array}{l}5.2 \pm 0.2 \\
4.9-5.5\end{array}$ & $\begin{array}{c}5.3 \pm 0.2 \\
4.9-5.6 \\
(n=26)\end{array}$ & $\begin{array}{l}5.2 \pm 0.1 \\
5.0-5.5\end{array}$ & $\begin{array}{l}5.3 \pm 0.2 \\
5.1-5.5\end{array}$ \\
\hline $\begin{array}{l}\text { Length of } \\
\text { mandible (ML) }\end{array}$ & $\begin{array}{c}16.8 \pm 0.4 \\
16.3-17.3\end{array}$ & $\begin{array}{c}16.3 \pm 0.5 \\
15.7-16.9\end{array}$ & $\begin{array}{c}15.2 \pm 0.5 \\
14.6-16.2 \\
(n=9)\end{array}$ & $\begin{array}{c}15.3 \pm 0.5 \\
14.0-16.0 \\
(n=26)\end{array}$ & $\begin{array}{c}15.3 \pm 0.5 \\
13.8-15.8\end{array}$ & $\begin{array}{c}15.4 \pm 0.6 \\
14.3-16.0\end{array}$ \\
\hline $\begin{array}{l}\text { Length of } \\
\text { mandibular } \\
\text { toothrow (LTL) }\end{array}$ & $\begin{array}{l}8.8 \pm 0.2 \\
8.6-9.0\end{array}$ & $\begin{array}{l}8.6 \pm 0.3 \\
8.3-8.8 \\
(n=3)\end{array}$ & $\begin{array}{l}8.1 \pm 0.2 \\
7.7-8.3\end{array}$ & $\begin{array}{c}8.1 \pm 0.3 \\
7.4-8.5\end{array}$ & $\begin{array}{l}8.2 \pm 0.2 \\
7.8-8.4\end{array}$ & $\begin{array}{l}8.3 \pm 0.3 \\
7.9-8.6\end{array}$ \\
\hline $\begin{array}{l}\text { Height of coronoid } \\
\text { process }(\mathrm{CPH})\end{array}$ & $\begin{array}{c}3.9 \pm 0.1 \\
3.8-4.0\end{array}$ & $\begin{array}{c}3.8 \pm 0.3 \\
3.5-4.2\end{array}$ & $\begin{array}{c}3.5 \pm 0.3 \\
3.0-4.0\end{array}$ & $\begin{array}{l}3.7 \pm 0.2 \\
3.2-3.9\end{array}$ & $\begin{array}{c}4.0 \pm 0.2 \\
3.6-4.4\end{array}$ & $\begin{array}{c}4.1 \pm 0.2 \\
3.7-4.2\end{array}$ \\
\hline $\begin{array}{l}\text { Length of forearm } \\
\qquad(\text { FAL })^{2}\end{array}$ & $\begin{array}{c}34.8 \pm 0.6 \\
34.2-35.6\end{array}$ & $\begin{array}{c}33.8 \pm 0.6 \\
33.0-34.7 \\
(n=6)\end{array}$ & $\begin{array}{c}33.7 \pm 0.9 \\
32.3-34.9 \\
(n=15)\end{array}$ & $\begin{array}{c}33.6 \pm 0.8 \\
32.0-35.3\end{array}$ & $\begin{array}{c}35.4 \pm 1.1 \\
33.6-37.8\end{array}$ & $\begin{array}{l}34.8 \pm 0.7 \\
33.5-35.6\end{array}$ \\
\hline $\begin{array}{l}\text { Length of head } \\
\text { and body }\end{array}$ & $\begin{array}{c}61 \pm 1 \\
60-62\end{array}$ & $\begin{array}{c}57 \pm 4 \\
52-62 \\
(n=5)\end{array}$ & $\begin{array}{c}58 \pm 3 \\
54-63 \\
(n=10)\end{array}$ & $\begin{array}{c}58 \pm 3 \\
54-65 \\
(n=16)\end{array}$ & $\begin{array}{c}55 \pm 4 \\
45-60\end{array}$ & $\begin{array}{c}55 \pm 2 \\
51-57\end{array}$ \\
\hline Length of tail & $\begin{array}{c}8 \pm 1 \\
7-9\end{array}$ & $\begin{array}{c}9 \pm 2 \\
8-12 \\
(n=5)\end{array}$ & $\begin{array}{c}7 \pm 1 \\
5-9 \\
(n=10)\end{array}$ & $\begin{array}{c}8 \pm 2 \\
6-12 \\
(n=16)\end{array}$ & $\begin{array}{c}10 \pm 1 \\
8-14\end{array}$ & $\begin{array}{c}10 \pm 1 \\
8-12\end{array}$ \\
\hline $\begin{array}{l}\text { Length of hind } \\
\text { foot }\end{array}$ & - & $\begin{array}{l}11 \pm 1 \\
10-12 \\
(n=3)\end{array}$ & $\begin{array}{c}10 \pm 1 \\
9-12 \\
(n=10)\end{array}$ & $\begin{array}{c}10 \pm 1 \\
8-12 \\
(n=16)\end{array}$ & $\begin{array}{l}9 \pm 1 \\
8-10\end{array}$ & $\begin{array}{c}9 \pm 0.5 \\
8-9\end{array}$ \\
\hline Length of ear & - & $\begin{array}{l}13 \pm 2 \\
11-15 \\
(n=3)\end{array}$ & $\begin{array}{c}14 \pm 1 \\
11-16 \\
(n=10)\end{array}$ & $\begin{array}{c}14 \pm 1 \\
12-17 \\
(n=15)\end{array}$ & $\begin{array}{c}15 \pm 1 \\
14-16\end{array}$ & $\begin{array}{c}14 \pm 1 \\
13-15\end{array}$ \\
\hline Weight & - & $\begin{array}{c}8.7 \\
(n=1)\end{array}$ & $\begin{array}{l}7.0 \pm 0.5 \\
7.0-8.0 \\
(n=7)\end{array}$ & $\begin{array}{l}8.0 \pm 0.9 \\
7.0-9.0 \\
(n=9)\end{array}$ & $\begin{array}{c}8.7 \pm 0.8 \\
7.5-11.0\end{array}$ & $\begin{array}{c}8.6 \pm 0.7 \\
8.0-10.0\end{array}$ \\
\hline
\end{tabular}

\footnotetext{
${ }^{1}$ Except as noted.

${ }^{2}$ Female Lonchophylla fornicata have a longer mean FAL than males $(t=2.4495 ; d f=8 ; P<0.05)$. The differences between mean FAL for female and male $L$. concava $(t=1.3785 ; d f=40 ; 0.2>P>0.1)$ and $L$.
} $\operatorname{mordax}(t=1.3147 ; d f=20 ; 0.4>P>0.2)$ are not statistically significant. 
poeyi (Phyllonycterinae); and Brachyphylla caverarnum (Brachyphyllinae). I used the computer program PAUP $4.0 \mathrm{~b} 10$ for Macintosh computers (see Swofford 1998) to analyze the matrix. All characters were unordered and equally weighted. No topology for the outgroups was enforced. Parsimony analyses used the heuristic search option with a random addition sequence of 1000 replicates. Starting trees were via stepwise addition, and the branch-swapping algorithm was tree-bisection-reconnection (TBR). I also carried out bootstrap analyses of 1000 bootstrap repetitions with a random addition sequence of 100 replicates and TBR. Character evolution on the resultant trees was analyzed using MCCLADE 3.0 (Maddison \& Maddison 1992).

I examined specimens (see Appendix I) from the following collections (abbreviations in parentheses): American Museum of Natural History, New York (AMNH); Carnegie Museum of Natural History, Pittsburgh (CM); Field Museum, Chicago (FM); University of Kansas Natural History Museum, Lawrence (KU); Los Angeles County Museum, Los Angeles (LACM); Louisiana State University Museum of Zoology, Baton Rouge (LSU); Museum of Southwestern Biology, Albuquerque (MSB); Michigan State University, East Lansing (MSU); Museum of Texas Tech University, Lubbock (TTU); National Museum of Natural History, Washington, D.C. (USNM).

\section{Results}

The twelve species of Lonchophylla currently recognized often are divided into two size groups based on greatest length of skull (GLS; Taddei et al. 1983, Dávalos 2004, Woodman \& Timm 2006). GLS correlates poorly with other more typical proxies for body size, such as length of head and body or weight (Woodman \& Timm 2006), and the size division based on GLS does not reflect phylogenetic relationships within the genus as they are currently understood (e.g., Dávalos \& Jansa 2004). The division into size groupings is generally useful, however, for characterizing species and identifying specimens (Woodman \& Timm 2006). The "large" Lonchophylla (GLS $>24.5 \mathrm{~mm}$ ) are $L$. bokermanni, $L$. chocoana, L. handleyi, L. hesperia, $L$. orcesi, and L. robusta (Table 1). "Small" species (GLS $<24.5 \mathrm{~mm}$ ) include $L$. cadenai, L. concava, $L$. dekeyseri, $L$. mordax, L. pattoni, and L. thomasi. The new species is intermediate in size (GLS = 23.7-25.4, Table 1) and overlaps both smaller individuals in the large size group (especially L. bokermanni and L. hesperia) and larger individuals from the small size group (especially L. concava and $L$. $\operatorname{mordax}$, ).

Lonchophylla fornicata, new species

Pacific Forest Long-tongued Bat Fig. 1

Glossophaga soricina: M. E. Thomas 1972:157 (part); not Glossophaga soricina (Pallas).

Lonchophylla mordax: McCarthy et al. 2000:958 (part); not Lonchophylla mordax O. Thomas.

Lonchophylla concava: Woodman \& Timm 2006:475 (part); not Lonchophylla concava Goldman.

Holotype.-Dried skin and skull of adult male, National Museum of Natural History (USNM) number 483360, collected 18 November 1966 by Maurice Earl Thomas (original number 914). Skull in good condition; skin missing small patches of fur on posterior dorsum and a large patch of fur on posterior venter.

Type locality. $-29 \mathrm{~km}$ SE of Buenaventura, $75 \mathrm{~m}$ elevation, east bank of Río Zabaletas, across from the village of Zabaletas $\quad\left[3^{\circ} 44^{\prime} \mathrm{N}, \quad 76^{\circ} 57^{\prime} \mathrm{W}\right.$-Paynter 1997], Valle del Cauca Department, Colombia. 


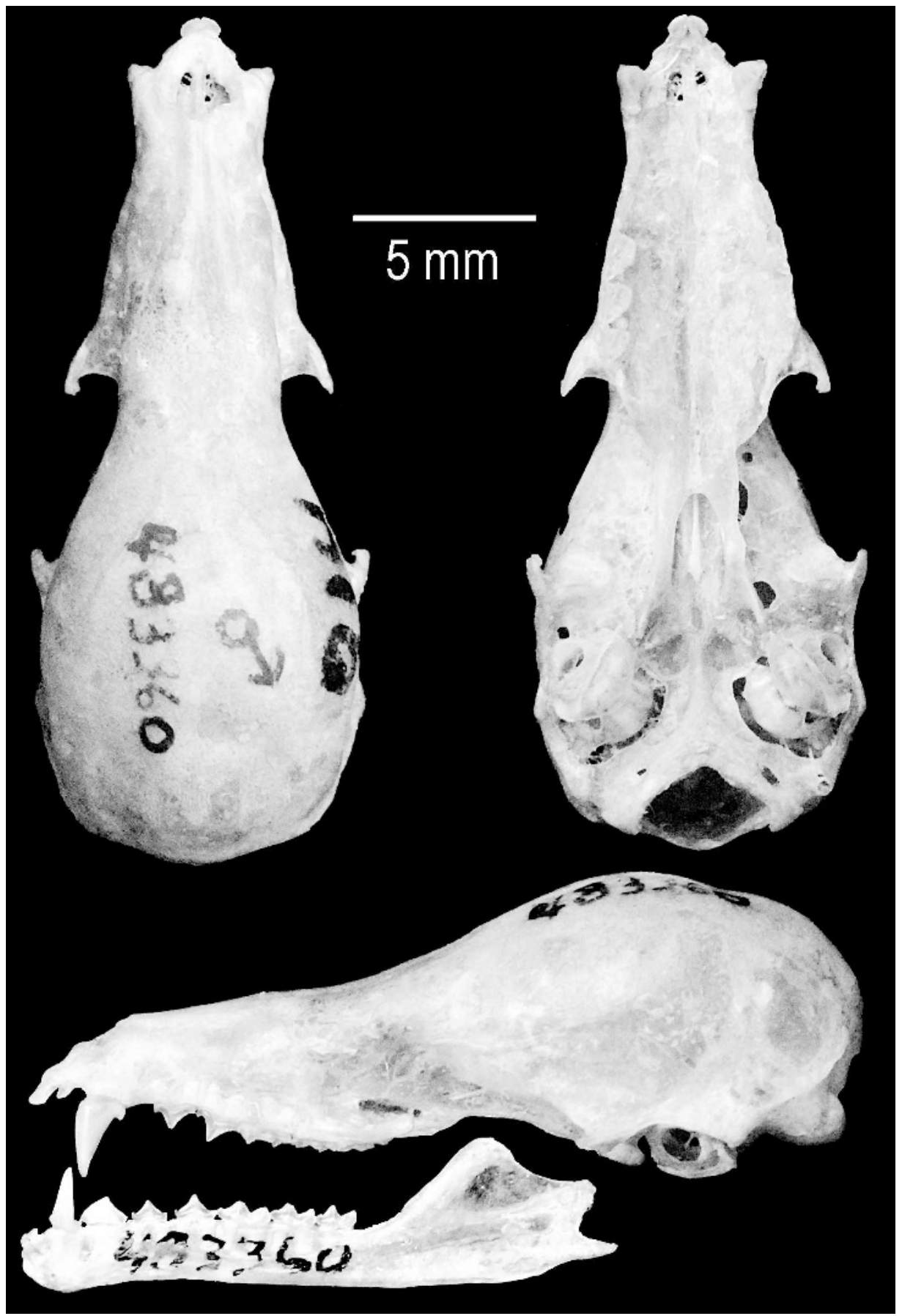

Fig. 1. Dorsal and ventral views of the cranium and lateral view of the cranium and mandible of Lonchophylla fornicata. 
Referred specimens (9).--One male (USNM 446466) taken 17-19 Apr 1967 by M. E. Thomas (original number 925) at the type locality; 1 male (FM 89572) obtained 18 Feb 1959 by Kjell von Sneidern, and 4 females (one pregnant) and 2 males (LACM 18771-18776) collected 27-28 Aug 1959 by Melbourne Armstrong Carriker, Jr., at La Guayacana (ca. $1^{\circ} 26^{\prime} \mathrm{N}, 78^{\circ} 27^{\prime} \mathrm{W}$ ), $225 \mathrm{~m}$, Nariño Department, Colombia; 1 male (CM 112585) collected 28 Dec 1991 by T. J. McCarthy at the Lita train tunnel, ca. $1.7 \mathrm{~km}$ east of Lita train station (ca. $\left.0^{\circ} 52^{\prime} \mathrm{N}, \quad 78^{\circ} 28^{\prime} \mathrm{W}\right), \quad 512 \mathrm{~m}$, Imbabura Province, Ecuador.

Etymology.-The species name fornicata is a Latin adjective meaning "arched," and it was chosen to communicate the similarity of the new species to Lonchophylla concava (concava being a Latin adjective meaning "hollowed," "arched inward," most likely in reference to the deeply arched posterior portion of the palate).

Distribution.-Known from the Pacific coastal plain of southwestern Colombia and northwestern Ecuador; elevational distribution from $75 \mathrm{~m}$ to just above $500 \mathrm{~m}$ (Fig. 2).

Diagnosis.-Based on GLS, L. fornicata is a medium-sized member of the genus, most easily distinguished from $L$. chocoana, L. handleyi, $L$. hesperia, $L$. orcesi, and Platalina genovensium by its shorter skull (GLS < 26.0), and from Lonchophylla cadenai, L. dekeyseri, $L$. pattoni, L. thomasi, and Lionycteris spurrelli by its longer skull (GLS > 23.0). Lonchophylla fornicata is further distinguished from L. bokermanni, L. chocoana, L. handleyi, L. hesperia, L. orcesi, and Platalina genovensium by its shorter forearm (FA < 36.5), and from Lonchophylla cadenai by its longer forearm (FA $\geq$ 33.0). From other Lonchophylla, L. fornicata can be distinguished by its short, brown dorsal pelage (in contrast to those of L. pattoni and L. robusta); long,

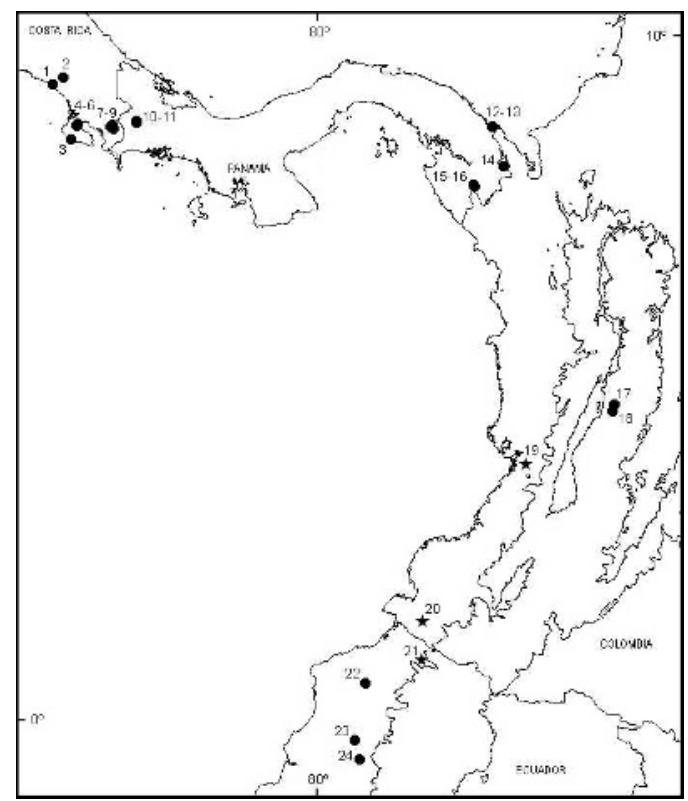

Fig. 2. Map of southern Central American and northwestern South America, illustrating the distribution of specimens of Lonchophylla fornicata (stars) and L. concava (dots).

narrow, uninflated rostrum (in contrast to those of $L$. chocoana, $L$. dekeyseri, $L$. handleyi, L. hesperia, L. mordax, L. orcesi, L. robusta); narrow, uninflated supraorbital region (in contrast to those of $L$. cadenai, L. concava, L. handleyi, $L$. hesperia, L. pattoni, L. robusta, L. thomasi) typically lacking distinct lateral projections (in contrast to $L$. cadenai, $L$. robusta); more posterior placement of posterior border of anteorbital foramen (in contrast to L. bokermanni, L. cadenai, L. chocoana, L. mordax, L. pattoni, L. robusta, $L$. thomasi) the outer margin of which does not project beyond the lateral outline of the rostrum (in contrast to $L$. cadenai, L. pattoni, L. thomasi); deeply grooved upper canine (in contrast to those of L. chocoana, L. dekeyseri, $L$. handleyi, L. mordax, L. robusta); P4 with obvious, rooted lingual cusp (in contrast to those of $L$. cadenai, $L$. chocoana, $L$. dekeyseri, L. handleyi, L. mordax, L. orcesi, L. pattoni, L. robusta, L. thomasi); deep depression along midline of posteri- 
or portion of palate (in contrast to those of L. cadenai, L. chocoana, L. dekeyseri, L. hesperia, L. mordax, L. pattoni, L. thomasi); posterior position of posterior border of palate (in contrast to those of $L$. dekeyseri, L. hesperia, L. mordax,); long, open, U-shaped to W-shaped mesopterygoid fossa, often with median posterior projection of palate (in contrast to those of L. cadenai, L. pattoni, L. thomasi); narrow, uninflated pterygoid processes (in contrast to those of $L$. cadenai, $L$. pattoni, L. thomasi); shallow basisphenoid pits (in contrast to those of L. cadenai, $L$. chocoana, L. hesperia, L. mordax, L. pattoni, L. thomasi) separated by a broad median septum (in contrast to those of $L$. cadenai, L. pattoni, L. thomasi); long, slender mandible (in contrast to those of L. bokermanni, L. cadenai, L. chocoana, $L$. dekeyseri, L. handleyi, L. hesperia, $L$. mordax, L. orcesi, L. robusta, L. thomasi) with low, rounded coronoid processes (in contrast to those of $L$. cadenai, $L$. dekeyseri, L. hesperia, L. mordax, $L$. orcesi, L. pattoni, L. robusta) and long articular process; p2 lacking posterior cusp (in contrast to those of $L$. bokermanni, L. cadenai, L. chocoana, L. dekeyseri, L. handleyi, L. mordax, L. orcesi, L. pattoni, L. robusta, L. thomasi); gap between i2 and lower canine greater than long dimension of i2 (in contrast to $L$. bokermanni, L. cadenai, L. chocoana, L. dekeyseri, L. handleyi, L. mordax, L. orcesi, L. robusta, L. thomasi).

Description._Lonchophylla fornicata is a medium-sized species in the genus as measured either by greatest length of skull or by head and body length, and it has a relatively short forearm (Table 1 ). Dorsal pelage is typically 5-7 $\mathrm{mm}$ long and strongly bicolored. The paler bases (ca. 70-80\% of the length of the hairs) are creamy brown (Avellaneous to Drab) in color, in contrast to the pale- to mediumbrown tips, which vary from Buffy Brown on lower back to Natal Brown near the head. Ventral pelage is generally mono- colored and varies from Avellaneous to Wood Brown. Genal vibrissae are absent, and there are three interramal vibrissae. An indistinct central rib extends to tip of noseleaf. In dorsal view, the rostrum is long and narrow, and it is not inflated above M1s, resulting in nearly parallel lateral outlines. The supraorbital region is narrow, not inflated, and typically lacks lateral projections. The posterior border of the anteorbital foramen is typically within the outline of the rostrum. In lateral view, the posterior border of the anteorbital foramen is typically between P4 and M1. In palatal view, obvious gaps are present between I1 and I2. P4 lacks a rooted lingual cusp. The transition of the posterior palate to the postdental palate is interrupted by deep midline depression. That portion of the palate posterior to M3 is longer than M3. The posterior margin of the palate typically extends posterior to the optic foramen and is near the anterior edge of the sphenoidal fissure. The mesopterygoid fossa is long, open, and U-shaped or Wshaped anteriorly; the anterior border of the mesopterygoid fossa typically is modified by a median projection of palate. The pterygoid processes are relatively narrow, and are not inflated. The basisphenoid pits are shallow, and the intervening septum is broad with rounded edges. The mandible is long and relatively slender. The coronoid process is low (slightly above level of the articular condyle) and broadly rounded. The articular process is long. The lower second premolar (p2) lacks a posterior cusp (hypoconid). In dorsal view, the gap between i2 and the canine is typically greater than the long dimension of i2.

Comparisons.-Lonchophylla fornicata is readily distinguished from Lonchophylla bokermanni, L. chocoana, L. handleyi, L. hesperia, L. orcesi, and L. robusta by its much shorter forearm (FA < 36.0 - Table 1), and from $L$. cadenai by its longer forearm ( $\mathrm{FA} \geq 33.0$ ). It is 
distinguished from L. chocoana, L. handleyi, L. hesperia, and $L$. orcesi by its shorter skull (GLS $<26.0$ ), and from $L$. cadenai, $L$. dekeyseri, $L$. pattoni, and $L$. thomasi by its longer skull (GLS > 23.0). In several dimensions, Lonchophylla fornicata is most similar to $L$. cadenai, $L$. concava, $L$. dekeyseri, $L$. mordax, $L$. pattoni, and L. thomasi; additional comparisons with these taxa follow.

Lonchophylla cadenai, L. pattoni, and L. thomasi: In addition to its longer skull (GLS > 23.0), L. fornicata has a longer, narrower rostrum; narrower, less inflated supraorbital region; more posteriorly located posterior border of anteorbital foramen (typically between P4 and M1 rather than above $\mathrm{P} 3$ or $\mathrm{P} 4$ ) that does not project beyond the lateral outline of the rostrum; longer, narrower palate; lingual cusp on P4 lacking; a deep depression along midline of posterior palate; a long, open U-shaped or W-shaped mesopterygoid fossa, with median projection of palate; narrow, uninflated pterygoid processes; broader septum separating basisphenoid pits; more rounded coronoid process; posterior cusp on p2 lacking; greater gap between i2 and canine.

Lonchophylla concava: Lonchophylla fornicata is closest morphologically to this species, from which it differs in its longer skull, wider posterior palate (as measured by MMB), and proportionally greater zygomatic breadth (Fig. 3A), supraorbital breadth, and lengths of maxillary and mandibular toothrows (Fig. 3B); longer maxillary toothrow relative to mandibular toothrow (Fig. 3C); greater height of coronoid process relative to mandibular toothrow (Fig. 3D).

Lonchophylla dekeyseri: In addition to its longer skull (GLS > 23.0), L. fornicata has a longer, narrower, and less inflated rostrum; more posteriorly located posterior border of anteorbital foramen (typically between $\mathrm{P} 4$ and $\mathrm{M} 1$ rather than above posterior root of $\mathrm{P} 4$ ); longer, broader palate; lingual cusp on P4 lack- ing; a deep depression along midline of posterior palate; shallower basisphenoid pits; lower, more rounded coronoid process; posterior cusp on p2 lacking; greater gap between i2 and canine.

Lonchophylla mordax: Lonchophylla fornicata has a longer, narrower, less inflated rostrum; more posteriorly located posterior border of anteorbital foramen (typically between P3 and M1 rather than between anterior and posterior roots of P4); longer, broader palate; lingual cusp on P4 lacking; a deep depression along midline of posterior palate; shallower basisphenoid pits; lower, more rounded coronoid process; posterior cusp on p2 lacking; greater gap between i2 and canine.

Multivariate analysis. - A plot of factor scores from a PCA comparing $L$. concava, L. fornicata, and L. mordax (Fig. 4) shows that Lonchophylla concava and $L$. mordax overlap nearly completely on PC 1 , which represents overall size (Table 2). In contrast, L. fornicata typically is larger than either of those species. Along PC 2, L. mordax is almost entirely separated from $L$. concava and $L$. fornicata, reflecting its generally shorter palate, narrower supraorbital region, higher coronoid process, and longer forearm (Table 2).

A plot of factor scores from a second PCA comparing just $L$. concava and $L$. fornicata (Fig. 5), shows the two species separate along PC 1, which emphasizes the greater size of L. fornicata (Table 3). Despite the wide distribution of specimens, from southern Costa Rica through western Ecuador, L. concava is relatively uniform in size, with no indication of clinal variation. Specimens of $L$. fornicata have a size distribution that is nearly as great as that of $L$. concava despite their more limited geographic range. Along PC 2 ("length" vs. "breadth;" see Table 3), the two species overlap considerably, although $L$. fornicata has a much narrower range of variation. Within $L$. concava, there appears to be a tendency 

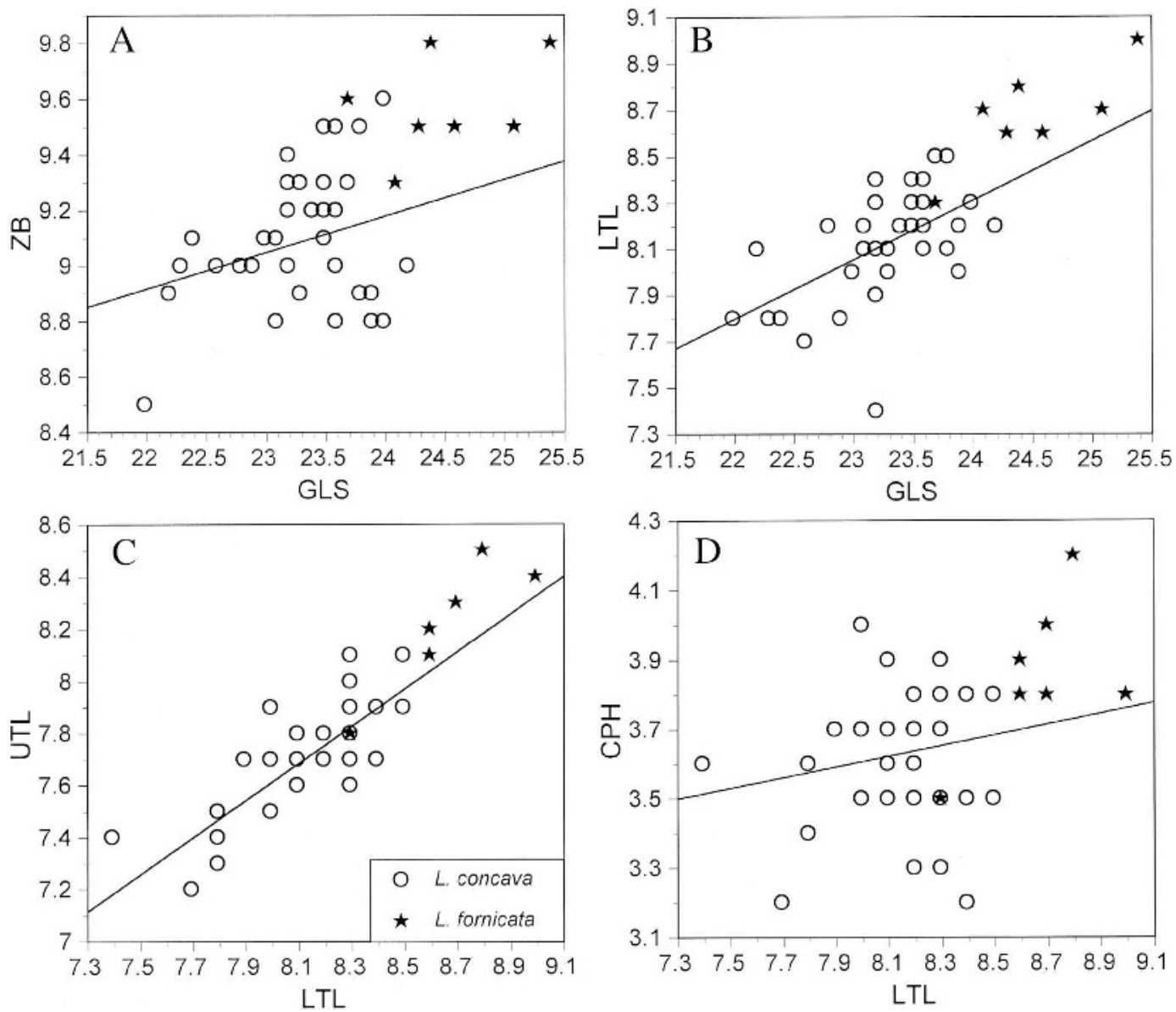

Fig. 3. Bivariate plots of variables measured from L. concava and L. fornicata. Abbreviations are explained in Table 1. Regressions are based only on $L$. concava and are extended through plots of $L$. fornicata. A, Bivariate plot of zygomatic breadth (ZB) and greatest length of skull (GLS), illustrating the longer and relatively broader skull of $L$. fornicata $(\mathrm{ZB}=6.03+0.131 \mathrm{GLS} ; F=2.91, p=0.097)$. B, Bivariate plot of length of mandibular toothrow (LTL) and greatest length of skull (GLS), illustrating the longer skull and relatively longer toothrow of $L$. fornicata $(\mathrm{LTL}=2.16+0.256 \mathrm{GLS} ; F=16.71, p=0.000$ ). C, Bivariate plot of length of maxillary toothrow (UTL) and length of mandibular toothrow (LTL), illustrating both the longer maxillary and mandibular toothrows of L. fornicata and the longer maxillary toothrow relative to mandibular toothrow in that species $(\mathrm{LTL}=1.32+0.884 \mathrm{UTL} ; F=61.65, p=0.000$ ). $\mathrm{D}$, Bivariate plot of height of coronoid process (CPH) and length of mandibular toothrow (LTL), illustrating the longer toothrow and relatively higher coronoid process of $L$. fornicata $(\mathrm{CPH}=2.37+0.154$ LTL; $F=1.12, p=0.297$ ). The slopes of the regressions for plots A and D are not significantly different from zero.

for Costa Rican, Colombian, and Panamanian specimens to have shorter, broader skulls and longer forearms relative to Ecuadorian specimens. Along PC 3 (SB vs. CPH; not shown), the two species also overlap considerably.

Sexual dimorphism.-Among the Lonchophyllini, males and females are generally similar in size and proportions, although geographically-constrained samples are still too small and uneven to have great confidence in statistical tests. Woodman \& Timm (2006) found that their sample of female Lonchophylla thomasi exhibited a clear tendency to have a longer skull, narrower zygomatic breadth (but 


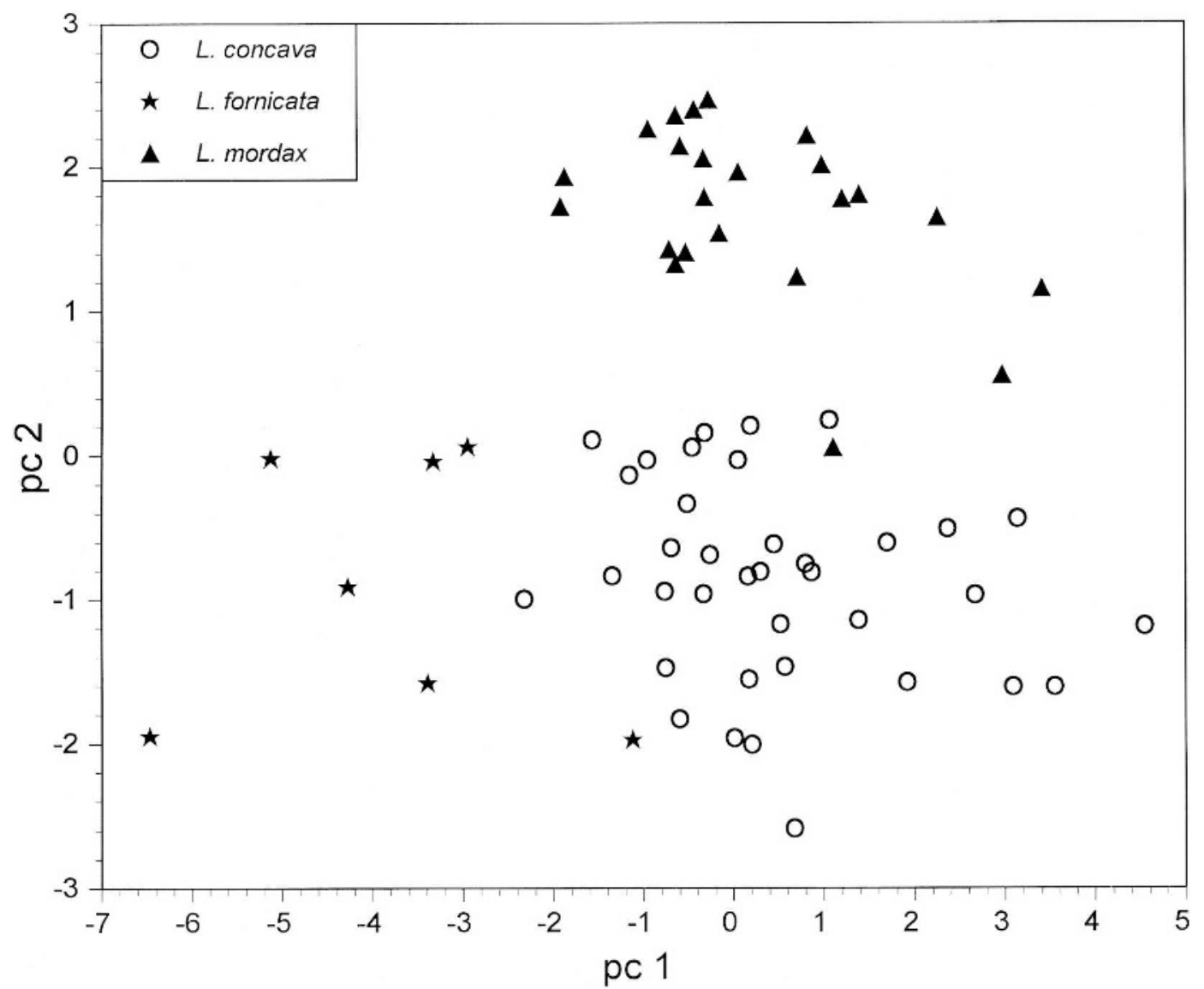

Fig. 4. Plot of scores on the first and second axes from PCA of eight variables measured from $37 L$. concava, 7 L. fornicata, and 23 L. mordax. Factors loadings on PC 1 are negative (Table 2), so the largest individuals have the most negative scores on that axis.

Table 2.-Factor loadings for the first two axes from PCA of eight variables from 37 L. concava, 7 L. fornicata, and 23 L. mordax (Fig. 4).

\begin{tabular}{lcc}
\hline & \multicolumn{2}{c}{ Correlations } \\
\cline { 2 - 3 } Variable & PC 1 & PC 2 \\
\hline GLS & -0.460 & -0.065 \\
PL & -0.323 & -0.463 \\
SB & -0.251 & -0.345 \\
ZB & -0.354 & 0.003 \\
UTL & -0.464 & 0.102 \\
LTL & -0.454 & -0.004 \\
CPH & -0.190 & 0.594 \\
FAL & -0.195 & 0.547 \\
Eigenvalue & 3.8529 & 1.9880 \\
Proportion of variation & $48.2 \%$ & $24.8 \%$ \\
\hline
\end{tabular}

equal or broader postorbital region), shorter coronoid process of the mandible, and longer forearm than males, but few of these differences were statistically significant. I found that female Lonchophylla concava, L. fornicata, L. mordax, and Lionycteris spurrelli show many of the same tendencies, with the exceptions that zygomatic breadth averages slightly greater in male Lionycteris spurrelli and is equal in male and female L. mordax; and the coronoid process tends to be higher in female L. fornicata (Table 1). Moreover, the difference in forearm length in $L$. fornicata is statistically significant, although this may be a result of the low sample sizes available. In multivariate 


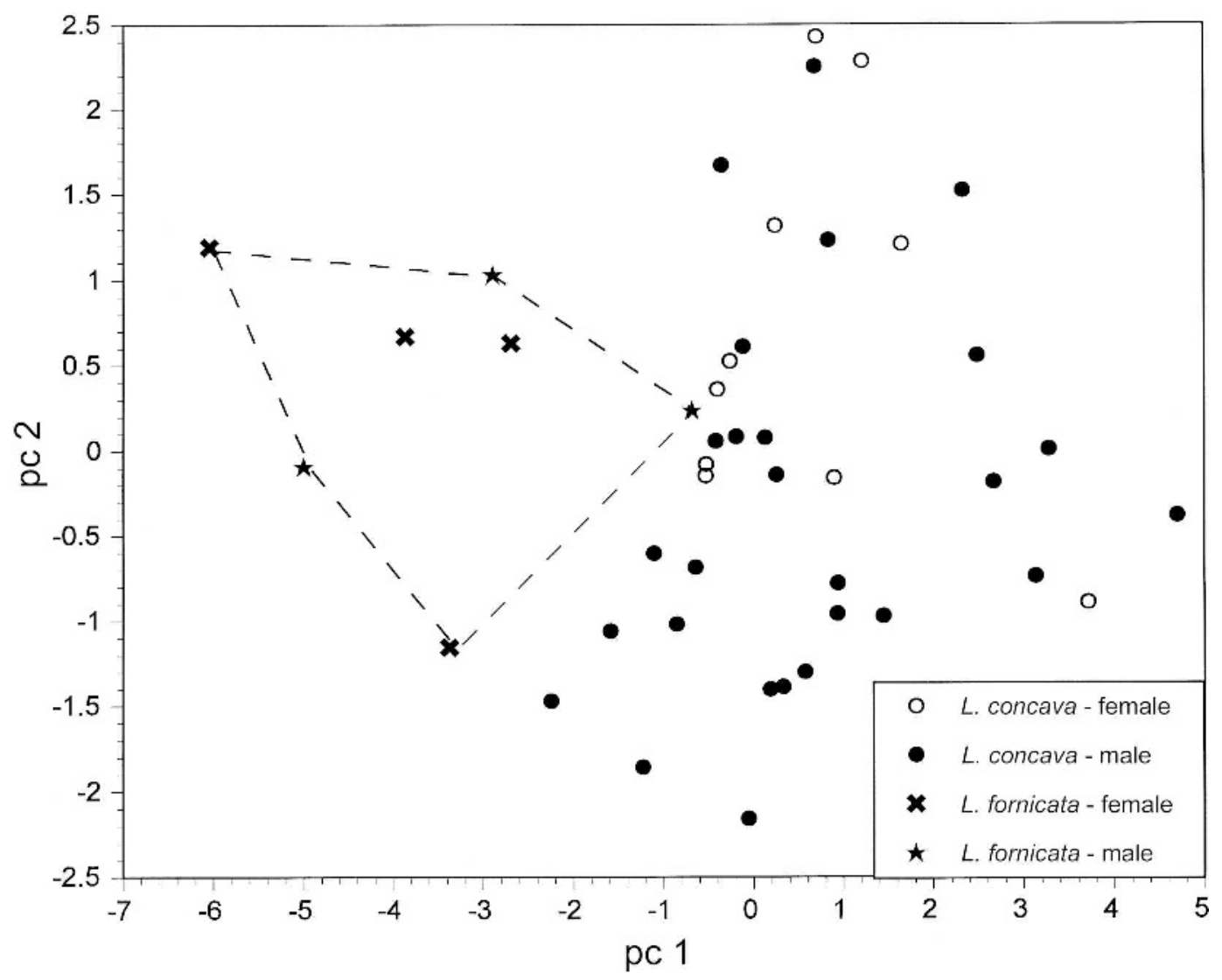

Fig. 5. Plot of scores on the first and second axes from PCA of eight variables measured from $37 L$. concava and 7 Lonchophylla fornicata. Factors loadings on PC 1 are negative (Table 3), so the largest individuals have the most negative scores on that axis.

Table 3.-Factor loadings for the first two axes from PCA of eight variables from 37 L. concava and 7 L. fornicata, (Fig. 5).

\begin{tabular}{lccc}
\hline & \multicolumn{3}{c}{ Correlations } \\
\cline { 2 - 4 } Variable & PC 1 & PC 2 & PC 3 \\
\hline GLS & -0.408 & 0.245 & -0.068 \\
PL & -0.330 & 0.573 & -0.089 \\
SB & -0.273 & -0.481 & -0.619 \\
ZB & -0.346 & -0.240 & 0.003 \\
UTL & -0.433 & 0.087 & 0.117 \\
LTL & -0.404 & 0.249 & -0.061 \\
CPH & -0.294 & -0.335 & 0.762 \\
FAL & -0.305 & -0.376 & -0.082 \\
Eigenvalue & 4.7112 & 1.2715 & 0.7057 \\
Proportion of & & & \\
$\quad$ variation & $58.9 \%$ & $15.9 \%$ & $8.8 \%$ \\
\hline
\end{tabular}

space (Fig. 5), male and female $L$. concava overlap considerably but exhibit different centers of distribution along PC 2, which reflect the tendency of females to have longer, narrower skulls and lower coronoid processes (Table 3). A similarly subtle pattern of differentiation in multivariate space was reported between male and female L. thomasi (Woodman \& Timm 2006).

Possible sexual differences in measurable characters are small $(0-0.4 \mathrm{~mm}$ for cranial variables; $0.1-1.0 \mathrm{~mm}$ for length of forearm) and more often appear as general tendencies rather than as statistically significant distinctions. Their appearance across taxa, however, suggests that they may reflect real, if subtle, sexual 
differences that are difficult to detect. Specifically, females generally tend to have a longer, narrower skull; a shorter coronoid process of the mandible; and a longer forearm, on average, than males.

Remarks.-The holotype and a second specimen of L. fornicata were captured by M. E. Thomas across from the village of Zabaletas along the east bank of the Río Zabaletas, a tributary of the Río Anchicaya (M. E. Thomas 1972). This site is on the Pacific coastal plain in Premontane Rain Forest (IGAC 1988). Mean annual temperature in the region is ca. $25.5 \pm$ $2{ }^{\circ} \mathrm{C}$. There is a bimodal rainy season, and mean annual rainfall exceeds $7000 \mathrm{~mm}$. The driest period is January-March. The study site encompassed a gravel bar at the edge of the river and extended inland across a lightly-forested flood plain and approximately $100 \mathrm{~m}$ into dense rain forest on an older river terrace (M. E. Thomas 1972). Additional details of the Zabaletas site were provided by Thomas (1972) and by Woodman \& Timm (2006). Thomas captured 1646 individuals of 35 species of bats at Zabaletas from September 1966 through August 1967, with additional field work in June 1968 and January 1969. The total included six Lonchophylla cadenai, two L. chocoana, and two L. fornicata, indicating that these three species were syntopic at Zabaletas. Lonchophylla represented only $0.6 \%$ of captures, indicating that it was relatively uncommon to take any species of the genus here using traditional bat netting techniques.

All specimens of $L$. fornicata were collected on the Pacific side of the Andes in humid forest. A number of individuals are from about $225 \mathrm{~m}$ elevation at $\mathrm{La}$ Guayacana, also on the Pacific coastal plain of Colombia in Premontane Rain Forest (IGAC 1988). McCarthy et al. (2000) caught a male L. fornicata (CM $112585)$ at ca. $512 \mathrm{~m}$ elevation in a railroad tunnel near Lita, Imbabura Province, Ecuador, where it was apparently roosting. Other species taken with it were Balantiopteryx infusca, Carollia brevicauda, and Desmodus rotundus. Lita, which is in Premontane Wet Forest, experiences a year-round wet season with an annual precipitation of $3000-4000 \mathrm{~mm}$ and a mean annual temperature of 18 $22.4^{\circ} \mathrm{C}$ (Cañadas 1983).

Phylogenetic analysis.-Parsimony analysis of a data set of 64 characters (Table 4) yielded 16 shortest length trees (197 steps) with varied topologies. The strict consensus tree (Fig. 6) supports monophyly of the Lonchophyllini and identifies three terminal groups within the tribe, but deeper structure is obscured. One clade, identified in previous analyses (Dávalos \& Jansas 2004, Woodman \& Timm 2006), consists of Lonchophylla chocoana, L. handleyi, and L. robusta. In my analysis, these three taxa are linked with three other taxa in the form: ( $L$. mordax (Lionycteris spurrelli (Lonchophylla orcesi (L. chocoana (L. handleyi, L. robusta))))). A second clade, also identified previously (Woodman \& Timm 2006), consists of Lonchophylla cadenai, L. pattoni, and L. thomasi. The third grouping consists of $L$. bokermanni, $L$. concava, and L. fornicata. Few unambiguous characters support any of these branches, however.

Bootstrap analysis yielded a poorly resolved tree that was similar in many respects to that of Woodman \& Timm (2006). Like that tree and the parsimony tree, it recovered a sister relationship between $L$. handleyi and $L$. robusta and identified the clade of $L$. cadenai, $L$. pattoni, and L. thomasi. It also linked Platalina and Xeronycteris as sister taxa and recovered L. cadenai, L. pattoni, and L. thomasi as a clade. Unfortunately, most bootstrap supports were quite low.

I had been hopeful that the additional character codings for L. bokermanni and the removal of a redundant character would provide a greater resolution of relationships than that reported by 


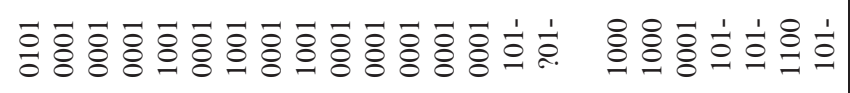

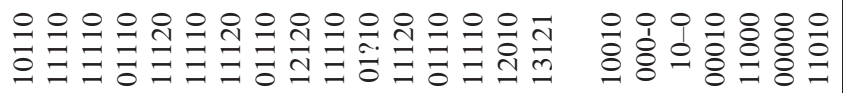

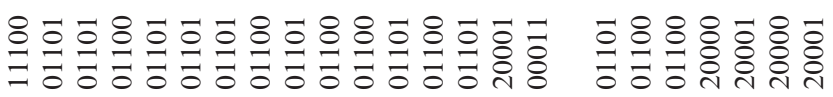

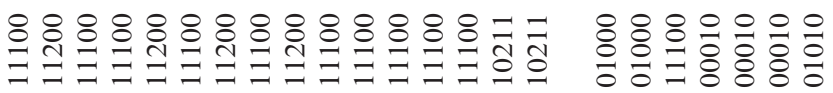

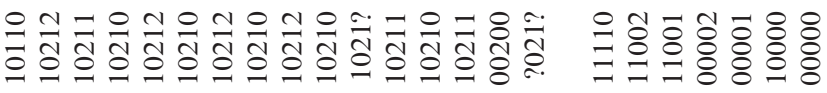

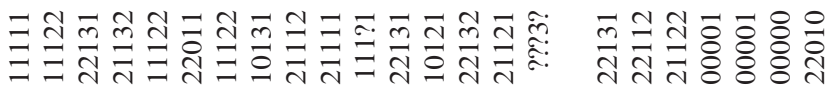

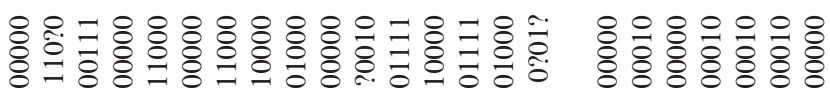

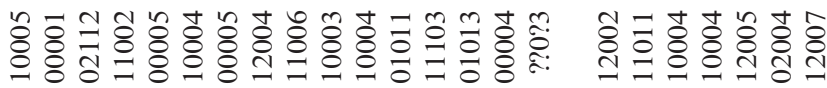

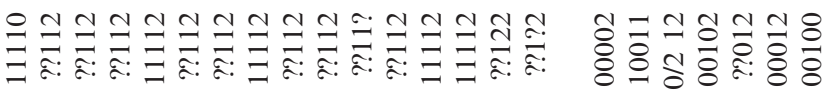
8

웣:

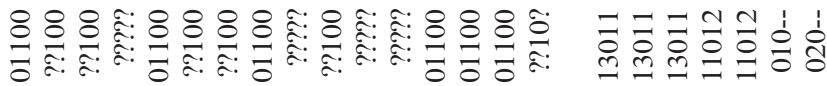

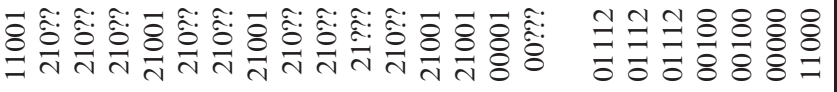

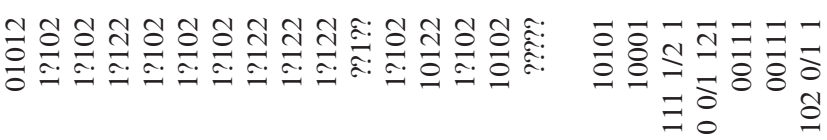

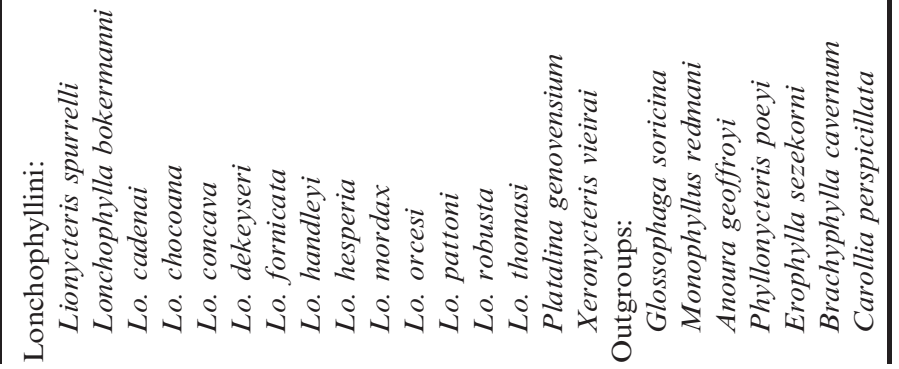




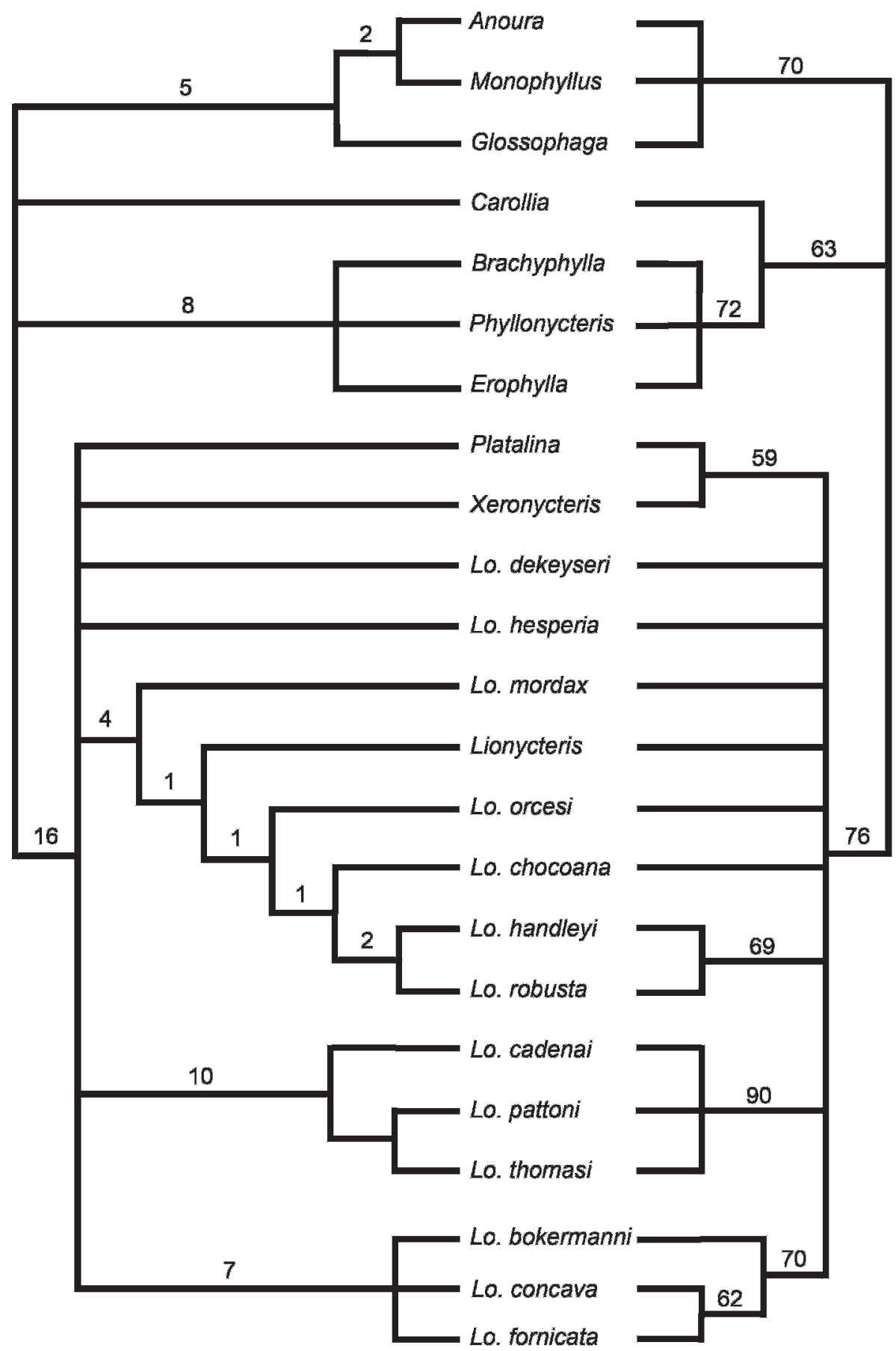

Fig. 6. Trees resulting from phylogenetic analysis of the Lonchophyllini using a data set of 64 characters. Strict consensus tree of 16 shortest length trees from parsimony analysis (left). Numbers of unambiguous changes is given above each branch. Tree statistics: length $=197 ; \mathrm{CI}=0.4721 ; \mathrm{RI}=0.6612 ; \mathrm{RC}=0.3122$; $\mathrm{HI}=0.5279$; CI excluding uninformative characters $=0.4667$; HI excluding uninformative characters $=$ 0.5333; G-fit $=-43.738 ; f$-value $=2262 ; f$-ratio $=0.7788$. Bootstrap majority consensus tree (right). Bootstrap supports $>50$ are listed above each branch; branches with supports $\leq 50$ are collapsed. 
Woodman \& Timm (2006). This did not turn out to be the case. Neither parsimony analysis nor bootstrap analysis was successful in identifying deeper structure within the Lonchophyllini, thus leaving unanswered the question of possibly paraphyly of Lonchophylla with respect to Lionycteris, Platalina, and/or Xeronycteris. Similarly, a deep division within Lonchophylla, hinted at by previous investigations (Dávalos \& Jansa 2004, Woodman \& Timm 2006), remains unconfirmed.

\section{Acknowledgments}

The following curators and collection staff graciously provided access to specimens under their care: Darrin Lunde, Nancy B. Simmons, Robert S. Voss, and Eileen Westwig (AMNH); Suzanne B. McLaren (CM); Lawrence R. Heaney, Bruce D. Patterson, and William S. Stanley (FMNH); Robert M. Timm (KU); Jim Dines (LACM); Mark S. Hafner (LSUMZ); Joseph A. Cook (MSB); Barbara Lundrigan (MSU); Heath Garner and Robert J. Baker (TTU). Alfred L. Gardner, Roy McDiarmid, Ron H. Pine, Robert P. Reynolds, and Nancy B. Simmons kindly provided valuable comments on previous versions of this manuscript.

\section{Literature Cited}

Albuja, V. L., \& A. L. Gardner. 2005. A new species of Lonchophylla Thomas (Chiroptera: Phyllostomidae) from Ecuador.-Proceedings of the Biological Society of Washington 118: 442-449.

Baker, R. J., S. R. Hoofer, C. A. Porter, \& R. A. Van Den Bussche. 2003. Diversification among New World leaf-nosed bats: An evolutionary hypothesis and classification inferred from digenomic congruence of DNA sequence.-Occasional Papers, Museum of Texas Tech University 230:i +1-32.

Cañadas, C. L. 1983. El mapa bioclimático y ecológico del Ecuador. Ministerio de Agricultura y Ganadería, Quito, 210 pp.
Carstens, B. C., B. L. Lundrigan, \& P. Myers. 2002. A phylogeny of the Neotropical nectarfeeding bats (Chiroptera: Phyllostomidae) based on morphological and molecular data.-Journal of Mammalian Evolution 9: 23-53.

Dávalos, L. M. 2004. A new Chocoan species of Lonchophylla (Chiroptera: Phyllostomidae). -American Museum Novitates 3426:1-14.

, \& S. A. Jansa. 2004. Phylogeny of the Lonchophyllini (Chiroptera: Phyllostomidae).- Journal of Mammalogy 85:404 413.

Goldman, E. A. 1914. Description of five new mammals from Panama.-Smithsonian Miscellaneous Collections 63:1-7.

Gregorin, R., \& A. D. Ditchfield. 2005. New genus and species of nectar-feeding bat in the tribe Lonchophyllini (Phyllostomidae: Glossophaginae) from northeastern Brazil.-Journal of Mammalogy 86:403-414.

Handley, C. O., Jr. 1966. Checklist of the mammals of Panama. Pp. 753-795 in R. L. Wenzel and V. J. Tipton, eds., Ectoparasites of Panama. Field Museum of Natural History, Chicago, xii +861 pp.

Holdridge, L. R. 1947. Determination of world plant formations from simple climatic data.Science 105:367-368.

, W. C. Grenke, W. H. Hatheway, T. Liang, \& J. A. Tosi, Jr. 1971. Forest environments in tropical life zones: a pilot study. Pergamon Press, New York, xxxii +747 pp.

IGAC (Instituto Geográfico Agustín Codazo). 1988. Suelos y bosques de Colombia. Santafé de Bogotá, 135 pp.

Koopman, K. F. 1994. Chiroptera: Systematics. Handbook of zoology, Vol. VIII: Mammalia. Walter de Gruyter, New York, vii + 217 pp.

Maddison, W. P., \& D. R. Maddison. 1992. Macclade: analysis of phylogeny and character evolution, version 3. Sunderland, Massachussetts: Sinauer Associates. 939 pp.

McCarthy, T. J., L. Albuja V, \& I. Manzano. 2000. Rediscovery of the brown sac-wing bat, Balantiopteryx infusca (Thomas, 1897), in Ecuador.- Journal of Mammalogy 81:958961.

Paynter, R. A., Jr. 1997. Ornithological gazetteer of Colombia. $2^{\text {nd }}$ edition. Museum of Comparative Zoology, Harvard University, Cambridge, Massachusetts, 537 pp.

Ridgway, R. 1912. Color standards and color nomenclature. Privately published, Washington, D.C., iii +43 pp, 53 pls.

Simmons, N. B. 2005. Order Chiroptera. Pp. 312 529 in D. E. Wilson and D. M. Reeder, eds., Mammal species of the world: A taxonomic and geographic reference. Third edition. Johns Hopkins University Press, Baltimore. 
Sokal, R. R., \& F. J. Rohlf. 1981. Biometry. 2nd edition. W. H. Freeman \& Company, New York, $\mathrm{xx}+859 \mathrm{pp}$.

Swofford, D. L. 1998. PAUP*. Phylogenetic analysis using parsimony (*and other methods). Version 4. Sunderland, Massachussetts: Sinauer Associates.

Taddei, V. A., L. D. Vizotto, \& I. Sazima. 1983. Uma nova espécie de Lonchophylla do Brasil e chave para identificação das espécies do gênero (Chiroptera, Phyllostomidae).Ciência e Cultura 35:625-629.

Thomas, M. E. 1972. Preliminary study of the annual breeding patterns and population fluctuations of bats in three ecologically distinct habitats in southwestern Colombia. Unpublished Ph.D. dissertation, Tulane University, vii $+161 \mathrm{pp}$.

Thomas, O. 1903. Notes on South-American monkeys, bats, carnivores, and rodents, with descriptions of new species.-Annals and Magazine of Natural History, series 7, 12: 455-464.

Wetterer, A. L., M. V. Rockman, \& N. B. Simmons. 2000. Phylogeny of phyllostomid bats (Mammalia: Chiroptera): data from diverse morphological systems, sex chromosomes, and restriction sites.-Bulletin of the American Museum of Natural History 248:1-200.

Woodman, N., \& R. M. Timm. 2006. Characters and phylogenetic relationships of nectarfeeding bats, with descriptions of new Lonchophylla from western South America (Mammalia: Chiroptera: Phyllostomidae: Lonchophyllini)._-Proceedings of the Biological Society of Washington 119:437-476.

\section{Appendix I: Specimens Examined}

Numbers in brackets associated with individual localities for Lonchophylla concava and L. fornicata key to the map in Fig. 2.

Lionycteris spurrelli (44).-BRAZIL: Espirito Santo: Santa Teresa (LACM 62878). COLOMBIA: Antioquia: Aljibes, 630 m (USNM 499297-499302); La Tirana, $520 \mathrm{~m}$ (USNM 499296); Providencia, $610 \mathrm{~m}$ (USNM 499303-499305). GUYANA: Cuyuni-Mazaruni: N slope of Mt. Roraima (KU 160837, 160838). Potaro-Siparuni: $25 \mathrm{~km} \mathrm{WNW} \mathrm{of}$ Kurupukari, 90 m (KU 155138, 155140-155144, 155146, 155148). PERU: Madre de Dios: $102 \mathrm{~km}$ beyond Quincemil at $\mathrm{km}$ post 145, ca. $1000 \mathrm{ft}$ (LSU 20201); Pasco: San Juan, 900 ft (USNM 364346). VENEZUELA: Amazonas: Morocoy, $161 \mathrm{~m}$ (USNM 407827, 407830); Paria, 114 m (USNM
491695); Raya, 135 m (USNM 407826). Bolivar: El Paují, $851 \mathrm{~m}$ (USNM 444674 444678, 444680444683, 444685, 444690, 444692, 444693, 444703, 444704); $18.8 \mathrm{~km} \mathrm{NE}$ of Icabarú (USNM 444674); Independencia, $824 \mathrm{~m}$ (USNM 444673).

Lonchophylla cadenai (8).-COLOMBIA: Valle del Cauca: Bajo Calima (USNM 338726); $29 \mathrm{~km} \mathrm{SE}$ Buenaventura, $75 \mathrm{~m}$ (USNM 446481, 446482, 483359-holotype, 483363-483365).

Lonchophylla chocoana (3).-COLOMBIA: Valle del Cauca: $29 \mathrm{~km}$ SE Buenaventura, 75 m (USNM 483361, 483362). ECUADOR: Esmeraldas: Los Pambiles (USNM 575171).

Lonchophylla concava (47).-COLOMBIA: Quindio: [16] Circasia (USNM 434372); [17] Acueducto Armenia (USNM 434371). COSTA RICA: San José: [1] $20 \mathrm{~km} \mathrm{SW}$ of San Isidro de General (KU 88034, 88035); [2] San Isidro del General (LACM 14997). Puntarenas: [3] Quebrada Camaronal, near Sirena Station, Corcovado National Park (USNM 565809); [4] 2 mi W of Rincón de Osa (KU 117457); [5] $2 \mathrm{~km} \mathrm{SW}$ of Rincón de Osa (MSB 26788); [6] Rincón (LACM 25368, 25369); [7] 40.9 km E (by road) of junction of HYW 2 and Rincón de Osa Road (CM 92496); [8] Finca Las Cruces, $2 \mathrm{~km} \mathrm{~S}$ of San Vito (MSB 26791); [9] 1-2 mi N of Villa Neilly (LACM 25530, 25531). ECUADOR: Esmeraldas: [18] Nueva Vida, $1.9 \mathrm{~km} \mathrm{~N}, 10.4 \mathrm{~km}$ E of CODESA SADE headquarters at Esmeraldas, $455 \mathrm{~m}$ (CM 112584). Manabi: [22] $45 \mathrm{~km} \mathrm{NE}$ of Chone (MSU 14995). Pichincha: [23] Río Palenque Science Center, $47 \mathrm{~km}$ (by road) S of Santo Domingo (USNM 528494-528500, 528582, 528583). PANAMA: Chiriquí: [10] 4 mi S El Volcán (USNM 336454); [11] $1 \mathrm{mi}$ E of Cuesta de Piedra, $2800 \mathrm{ft}$ (USNM 331254). San Blas: [12] Quebrada Venado, Armila (USNM 335181, 335182); [13] Puerto Obaldia, Quebrada de la Represa (USNM 335179). Darién: [14] Tacarcuna Village Camp, $3200 \mathrm{ft}$ (USNM 309384-309389, 519874); [15] Cana, 500-610 m (LSU 25498, 25499, 25502, 25503; TTU 3913039134; USNM 179621-holotype).

Lonchophylla dekeyseri (4).-BOLIVIA: Santa Cruz: Huanchaca, Site I, 508 m (USNM 584472, 584473). BRAZIL: Bahia: Cidade da Barra (USNM 238008)*. Pernambuco: Buíque (MSU 16411).

Lonchophylla fornicata (10).-COLOMBIA: Valle de Cauca: [19] Río Zabaletas, 29 km SE Buenaventura, across from Village of Zabaletas, $75 \mathrm{~m}$ (USNM 446466, 483360). Nariño: [20] La Guayacana, 225 m (FM 89572; LACM 18771-18776), 260 m. ECUADOR: Imbabura: [21] Train Tunnel,

*Woodman \& Timm (2006) incorrectly reported USNM 123392 from Lamaras as Lonchophylla dekeyseri and USNM 238008 from Cidade de Barra as L. mordax in their Specimens Examined. The identifications were inadvertently reversed. 
ca. $1.7 \mathrm{~km} \mathrm{E}$ of Lita Train Station, $512 \mathrm{~m} \mathrm{(CM}$ 112585).

Lonchophylla handleyi (6).-PERU: Cusco: Ridge Camp, 1000 m (USNM 588021). Huánuco: 6 km N of Tingo María (CM 98631, 98632). Junín: $13 \mathrm{mi} \mathrm{N}$ La Merced (AMNH 230215); $2 \mathrm{~km}$ NW San Ramón, 2900 ft (AMNH 230214). Pasco: San Juan (USNM 364347).

Lonchophylla hesperia (2).-PERU: Amazonas: $3.5 \mathrm{~km}$ E junction B Grande \& B rds (LACM 38848). La Libertad: Trujillo (USNM 283177).

Lonchophylla mordax (28).-BRAZIL: Bahia: Cidade da Barra (AMNH 235608); Fazenda Flamengo (CM 99413, 99414); Lamaras, $300 \mathrm{~m}$ (USNM 123392). Ceará: $4 \mathrm{~km} S E$ of Nova Olinda (CM 99415). Pernambuco: Fazenda Cantareno (CM 99416); Fazenda Guaraní (CM 99417); Fazenda Maniçoba (CM 99418, 99419); Fazenda Pomonha (CM 99420, 99421); Serrote das Lajes (CM 99422, 99425-99437); Serrote Gambá (CM 99444, 99446); Serrote Gritadeira (CM 99448).

Lonchophylla pattoni (1).-PERU: Río Madre de Dios: Reserva Cusco Amazónico, $200 \mathrm{~m}$ (KU 144232-holotype).

Lonchophylla robusta (37). C COLOMBIA: Tolima: Cunday (USNM 432178-432181); Melgar (AMNH 207820). COSTA RICA: Heredia: $1 \mathrm{~km}$ S, $11.5 \mathrm{~km}$ E San Miguel, 700 m (USNM $562767-$ 562773). ECUADOR: Unknown locality (USNM 522156). Guayas: Huerta Negra (USNM 498830, 498831, 522157, 534298, 534299, 534300); San Rafael (USNM 498827-498829). Pastaza: Mera (USNM 548069). PERU: Huánuco: $5 \mathrm{~km} \mathrm{SW}$ of Tingo María, Cueva de las Lechuzas (EC 3719, 3720, 3914, 3915, 3918, 3922). VENEZUELA: Barinas: Altamira, 794 m (USNM 419413); 7 km NNE Altamira, $1070 \mathrm{~m}$ (USNM 419415, 419417); $2 \mathrm{~km}$ SW Altamira, $620 \mathrm{~m}$ (USNM 419418, 419419). Bolivar: Ciudad Bolívar (AMNH 16120holotype); Zulia: Kasmera (USNM 419410); $10 \mathrm{~km}$ S, $18 \mathrm{~km} \mathrm{~W}$ of Machiques, $270 \mathrm{~m}$ (USNM 419409).

Lonchophylla thomasi (157).-BOLIVIA: El Beni: $1.5 \mathrm{~km}$ below Costa Marques, Brazil (AMNH 209358); $7 \mathrm{~km} \mathrm{~N}$ Lagoinha (AMNH 210688). La Paz: $1 \mathrm{mi} \mathrm{W}$ of Puerto Linares (MSU 32858; TTU 34812). Pando: Agua Dulce, 160 m (AMNH 262429, 262434). Santa Cruz: Huanchaca I, 508 m (USNM 584474-584476). BRAZIL: Amapá: vicinity of Serra do Navio (USNM 597536, 597537). Amazonas: Manaus (USNM 530958); $80 \mathrm{~km} \mathrm{~N}$ of Manaus (USNM 530959-530962). Pará: 52 km SSW Altamira (USNM 549361-549364, 549366-549369); Belém (USNM 361570, 361571, 393013, 393014, 460097, 460098); Inajatuba (AMNH 95495, 95772); Limôatuba (AMNH 95493); Mocajuba (AMNH 97271, 97272). COLOMBIA: Amazonas: Leticia (TTU 8834, 8847); Isla Santa Sofia (TTU 9059). Putumayo: San Antonio, Río Guamués
(FMNH 113421); Estación de Bombeo, Guamués (FMNH 113929). ECUADOR: Orellana: Río Yasuní (USNM 528325). Pastaza: Tiguino, $300 \mathrm{~m}$ [ $\left.1^{\circ} 07^{\prime} \mathrm{S}, \quad 76^{\circ} 57^{\prime} \mathrm{W}\right]$ (USNM 574510, 574511). FRENCH GUIANA: Saül (KU 135369-135371, 135400); Paracou (AMNH 266100, 266103, 266105, 266108, 266109, 266117, 267139, 267940, 267943). GUYANA: Barima-Waini: Baramita, $142 \mathrm{~m}$ (USNM 582299-582301). Potaro-Siparuni: Kurupukari, Base Camp, 70 m (KU 155157); 5 km SW of Kurupukari, Giaconda Camp, 75 m (KU 155152 155155); $25 \mathrm{~km}$ WNW of Kurupukari, $90 \mathrm{~m}$ (KU 155156). Upper Takutu-Upper Essequibo: Kuitaro River, near Miliwau Creek (USNM 338904, 338906). PANAMA: Bocas del Toro: Nuri, 2-25 m (USNM 575486, 575488-575491, 575493, 575494, 575496-575498). Darién: mouth of Río Paya, (USNM 306582). San Blas: Armila (USNM 335180). PERU: Amazonas: Río Cenepa, vicinity of Huampami, $700 \mathrm{ft}$ (MVZ 153321); km 381.4 of Carretera Corral Quemado-Nazareth, ca. $900 \mathrm{ft}$ (LSU 18422). Cuzco: Armihuari, $545 \mathrm{~m}$ (USNM 582794); Pagoreni, 465 m (USNM 577763); 40 km by road E of Quincemil (LSU 18860). Нuánuco: $6 \mathrm{~km} \mathrm{~N}$ of Tingo María (CM 98649). Madre de Dios: Hacienda Amazonia, $1050 \mathrm{~m}$ (FMNH 138911); Hacienda Erika, 350 m (MVZ 166627; UMMZ 160708, 160710); km 105, road from Puerto Maldonado to Quincemil, ca. $500 \mathrm{ft}$ (LSU 18861); Refugio Juliaca, $200 \mathrm{~m}$ (USNM 579632); Lago Sandoval (MVZ 157669). Loreto: San Jacinto, $175 \mathrm{~m}$ (KU 158056-158061); Teniente López, $175 \mathrm{~m}$ (KU 158062, 158063). Pasco: San Juan, $900 \mathrm{ft}$ (AMNH 230281); San Pablo, $900 \mathrm{ft}$ (AMNH 230282-230284). Puno: Fila Boca Guacamayo, $360 \mathrm{~m}$ (USNM 579631). Ucayali: Balta, $300 \mathrm{~m}$ (LSU 12096-12102，14119，14120，16486-16488; MVZ 136425, 136431, 136432, 136434, 136435, 136437); $59 \mathrm{~km} \mathrm{SW}$ of Pucallpa (USNM 499018). SURINAME: Brokopondo: $8 \mathrm{~km} \mathrm{~S}, 2 \mathrm{~km} \mathrm{~W}$ of Brownsweg (CM 63713, 63715). Marowijne: $3 \mathrm{~km}$ SW of Albina (CM 76778, 76779). Sipaliwini: Avanavero (TTU 33709); Bitagron (CM 63722, 63723); Sipaliwini Airstrip (CM 63721); $1 \mathrm{~km} \mathrm{~N}$ of Rudi Kappel Airfield, 300 m (CM 63716); Voltz Berg (CM 63725, 63726); $24 \mathrm{~km} \mathrm{S,} 60 \mathrm{~km} \mathrm{E}$ of Apoera (CM 63717-63720); Raleigh Falls (CM 63724). VENEZUELA: T. F. Amazonas: Capibara, 130 m (USNM 415387, 415388); 5 km E San Carlos de Río Negro, 120 m (FMNH 137268, 137269); ca. $7 \mathrm{~km} \mathrm{E}$ of San Carlos de Río Negro (USNM 560560); Raya, 135 m (USNM 407802, 407803); San Juan, 155 m (USNM 407798, 407799, 407801); Tamatama, $135 \mathrm{~m}$ (USNM 407796, 407797). Bolivar: Ciudad Bolívar (AMNH 16120-holotype); El Manaco, $150 \mathrm{~m}$ (USNM 385753); $50 \mathrm{~km} \mathrm{SE} \mathrm{El}$ Manteco, 350 m (USNM 385751, 385752); Santa Lucía de Surukún, 851 m (USNM 456537). 
Platalina genovensium (1).-PERU: Arequipa: Caravelí (USNM 268765).

\section{Appendix II: Character Codings For Phylogenetic Analysis}

\section{External characters:}

1. Pelage: differentiated into under hair and over hair (0); lacking over hair (1).

2. Majority of scale margins on hairs: entire (0); toothed (1).

3. Dorsal fur: unicolored (0); bicolored (1).

4. Genal vibrissae: absent (0); with single vibrissa in each cluster (1); two vibrissae in each cluster (2).

5. Interramal vibrissae: one vibrissa (0); two vibrissae (1); three vibrissae (2).

6. Central rib of noseleaf: absent (0); restricted to proximal portion of spear (1); extending to distal tip of spear (2).

7. Internarial region: smooth (0); with line of papillae (1).

8. Chin: without central cleft (0); with central cleft (2).

\section{Hyoid musculature and tongue:}

9. M. ceratohyoideus: does not insert on stylohyal (0); or partly inserts on stylohyal (1).

10. M. genioglossus: inserts into ventral surface of tongue along more than half of its length (0); insert into posterior half to third of ventral surface of tongue (1); inserts into posterior quarter of ventral surface of tongue (2).

11. Anterolateral slip of M. sphincter colli profundus: present (0); absent (1)

12. $M$. crocopharyngeus: consists of a single large slip (0); two slips (1); three slips (2); more than three slips (3).

13. Lingual sulci: absent (0); present on lateral surface of tongue (1).

14. Hairlike papillae: confined to lateral margin of distal third of tongue, with a single line of papillae extending approximately to lateral circumvallate papillae (0); distributed around lateral margin and dorsum of distal third of tongue (1).

15. Hairlike papillae of tongue: fleshy and conical (0); fleshy and conical with filamentous tips (1); cylindrical with ellipse-shaped distal end (2).

16. Medial-posterior patch of anteriorly directed mechanical papillae of tongue: always absent (0); present in some individuals (1); always present (2).

17. Basketlike papillae of tongue: absent (0); present (1).

18. Lingual papillae anterior to main papillae: three small papillae (0); one papilla (1); no papilla (2).
19. Primary horny papillae: flanked by a pair of smaller horny papillae (0); variable (1); no smaller papillae (2).

20. Lingual arteries: paired, lingual veins not enlarged (0); single midline artery, lingual veins enlarged (1).

\section{Restriction sites:}

21. Restriction site 50 of transcribed portion of rDNA complex: present (0); absent (1).

22. Restriction site 53: absent (0); present (1).

Skull:

23. Zygomatic arch: complete (0); incomplete (1); polymorphic within species (2).

24. Length of skull (relative to least postorbital breadth): short [mean GLS/PO < 4.8] (0); long [mean GLS/PO = 5.0-5.5] (1); very long [mean GLS/PO > 5.9] (2).

25. Length of rostrum relative to length of braincase: short-measured from position of cribiform plate, rostrum less than $34 \%$ length of skull (0); long, 36-38\% (1); very long, >39\% (2).

26. Rostrum: slightly inflated (uninflated) (0); distinctly inflated (1).

27. Postorbital region: uninflated (0); slightly inflated (1); moderately inflated (2); strongly inflated (3).

28. Postorbital processes: absent (0); present (1).

29. Posterior margin of infraorbital foramen: within margin of rostrum (0); forms laterally-projecting lip (1).

30. Position of posterior margin of infraorbital foramen: above posterior root of P3 (0); between P3 and P4 (1); above anterior root of P4 (2); between roots of P4 (3); above posterior root of P4 (4); between P4 and M1 (5); above anterior root of M1 (6); between roots of M1 (7).

31. Deep midline depression on posterior palate: absent (0); present (1).

32. Length of palate immediately posterior to M3: short, Santerior-posterior length of M3 (0); long, $>$ length of M3 (1).

33. Shape of mesopterygoid fossa: long, open, Ushaped or W-shaped anteriorly (0); short, acute V-shaped anteriorly (1).

34. Medial projection of palate into mesopterygoid fossa: present (0); absent (1).

35. Pterygoid processes: slender, uninflated (0); inflated (1).

36. Basisphenoid pits: very shallow (0); shallow (1); deep (2).

37. Septum between basisphenoid pits: very broad (0); broad (1); narrow (2).

38. Posterolateral border of palate: concave (0); convex, projecting into zygomatic space (1). 
39. Position of posterior border of palate: posteromedial edge of palate well anterior to optic foramen (0); just anterior to or at posterior border of optic foramen (1); posterior to optic foramen and near anterior end of sphenoidal fissure (2); well posterior to optic foramen and near middle of sphenoidal fissure (3).

40. Coronoid process: very high (0); high (1); low [articular condyle nearly at level of tip of coronoid process] (2).

41. Height of articular condyle: about level with mandibular toothrow (0); above level of mandibular toothrow (1).

\section{Upper dentition:}

42. I1: distinctly larger than I2 (0); about equal in size with I2 (1).

43. First upper incisors: not projecting anteriorly (0); projecting slightly anteriorly (1); projecting greatly anteriorly (2).

44. Gap between I1 and I2: narrow (0); broad (1).

45. Anterior edge of canine: rounded (0); flattened (1); grooved by wear against lower canine (2).

46. Parastyle on P3: low, but distinct (0); very low, indistinct (1).

47. Paracone on P4: low (0); high (1).

48. Lingual cusp on P4: rooted lingual expansion of cingulum (0); obvious lingual cusp (1); lingual cusp absent or reduced (2).

49. Ectoloph of M1-M2: present (0); absent (1).

50. M1 and M2: in contact (0); not in contact diastema present (1).
51. Parastyle on M1 and M2: distinct and anterior to paracone (0); present, not anterior to paracone (1); absent (2).

52. Mesostyle M1 and M2: absent (0); present (1).

53. Metastyle on M1: reduced or absent (0); present (1).

54. Postprotocrista on M1, M2, and M3: present (0); reduced or absent (1)

55. Hypocone on M1, M2: present (0); absent (1).

56. Posthypocrista on M1, M2: present (0); absent (1).

57. Position of M3: located entirely posterior to anterior edge of base of zygomatic process (0); part of M3 anterior to base of zygomatic process (1); M3 entirely anterior to zygomatic process (2); M3 much anterior to zygomatic process (3).

\section{Lower dentition:}

58. Lower incisors: not trifid (0); trifid (1).

59. Gap between i2 and c1: absent, teeth essentially overlapping (0); small (1); large, at least as long as length of i2 (2).

60. Cingulum on c1: present (0); absent (1).

61. posterior cusp (hypoconid) on $\mathrm{p} 2$ : present (0); absent (1).

62. Elongate labial cusp (metacristid) on p3: absent (0); present (1).

63. Entoconid on $\mathrm{m} 1, \mathrm{~m} 2$, and $\mathrm{m} 3$ : present $(0)$; absent (1).

64. Strong pre-entocristid extending anteriorly from entoconid on $\mathrm{m} 1-\mathrm{m} 2$ : absent (0); present (1). 